\title{
INSURANCE AS A PREREQUISITE FOR RISK MANAGEMENT IN WORKING AND LIVING ENVIRONMENT
}

\author{
UDC 368:005.334
}

\author{
Snežana Živković, Aleksandra Ilić Petković \\ University of Niš, Faculty of Occupational Safety, Niš, Serbia
}

\begin{abstract}
Insurance is an economic and service activity that protects people and their property from the consequences of numerous hazards. Therefore, insurance companies face the risk of financial loss. Improperinsurance premiums caused by an inadequate risk assessment that is assumed in insurance are the most common cause of such losses. In order to minimize the possibility of unwanted losses, it is necessary to carry out adequate business management processes in insurance. In doing so, special attention should be paid to the risk assessment process. A quality risk assessment is of the utmost importance for the functioning of the overall insurance system. Insurance itself can play a significant role in managing the risks in working and living environment whereas the legal regulation gives security to the insurance entities.
\end{abstract}

Key words: insurance, risk assessment, working and living environment, regulations

\section{INTRODUCTION}

In modern business conditions, there is a number of adverse events, such as fires, floods, earthquakes, droughts, tornadoes, tsunamis, occupational injuries, thefts, and the like, which threaten the lives, property, and business of market entities. In addition to existing risks, new risks, which did not exist or were not present to a great extent before, are emerging. They further increase business uncertainty in the environment [13]. Along with increasing uncertainty, the risk management processes in all business areas have progressed. The aim is to reduce business uncertainty to the minimum and to an acceptable level.

Uncertain environmental conditions forced businesses to secure their business [13]. Traditionally, this function has been performed by insurance companies. However, the increase in overall uncertainty has not bypassed insurance companies and is largely affecting these businesses in particular [13].

Received April 20, 2020 / Accepted June 15, 2020

Corresponding author: Aleksandra Ilić Petković1

University of Niš, Faculty of Occupational Safety in Niš, Serbia, Čarnojevića 10a, 18000 Niš, Serbia

E-mail: aleksandra.ilic@znrfak.ni.ac.rs 
The basic mechanism for reducing uncertainty regarding uncertain business conditions of insurance companies is reflected in the adequately determined price of the risks it assumes, that is, in the adequately determined insurance premium [13].

Insurance can be defined and observed from several aspects. It is a discipline that studies the effects of risk realization, economic consequences of the risk realized and risk management in order to reduce or prevent the possibility of risk occurrence. Insurance involves a multidisciplinary approach - economic, legal, mathematical-statistical, accounting, ethical, etc. Insurance can also be seen as a remedy for disturbances that arise from the effects of destructive forces caused by nature or human destruction. Or, it is an institution that compensates for the damage done to the economy or humans, due to the effects of natural destructive forces or accidents. Finally, insurance involves the association of all those who are exposed to the same hazards, and the purpose of the association is to jointly endure the economic consequences of damage that will surely happen to at least one of them over a period of time [16].

The basic idea of insurance is the risk of losing the property due to the effects of an unexpected event and the risk of the damage to health or loss of life from an unexpected cause. Risk results in economic loss or moral loss. It is also characterized by reciprocity and solidarity, which means that damage caused by destructive forces or accidents over a period of time by certain groups of the same or similar risks is not borne by individuals but all those affected by the same risk. The entire group covers damage that only affects one member because he or she would not be able to economically bear it alone.

Insurance has three basic functions - property, financial and social protection [16]. Keeping assets is a basic function of insurance. It can be achieved directly - prevention of damage, i.e. elimination of the causes of natural destructive events or accidents and the struggle to avoid damage occurring or to minimize it, as well as indirectly - compensation for damage, i.e. paying the sum insured from the funds collected through premium payments. The financial function involves the payment of a premium in advance and the use of funds to make a profit that will be a function of the insurance fund. It represents one type of long-term savings. The social function implies that the person who loses property and who has insurance will not become a burden to the social funds of the state.

\section{RISK AND INSURANCE}

Insurance is an institution that compensates for the damage to property or persons resulting from the risks caused by force majeure or accidents [12]. The essence of insurance as an economic category is that property owners, who are exposed to certain hazards, directly or indirectly unite in order to jointly sustain the damage that could possibly cause any of them due to the realization of risks [3].

There are many definitions of risk in modern risk theory. How the risk will be defined depends on the criteria that are applied in defining the adverse event and its scope [13]. There is no one-for-all definition of risk, whether observed from a theoretical or practical perspective. Insurance risk itself is identified with the occurrence of an economically harmful event $[3,5]$. Risk is a condition in which there is a possibility of a negative deviation from the desired outcome we expect or hope [1]. Risk is a danger that affects property or life. It is an unexpected event, independent of our will [16].

Facing a risk occurs on a daily basis. Businesses face various risks in business communication when making decisions or market and business estimations. The same 
process takes place at an individual level in performing different social activities [13]. In both cases, we make decisions that bear the risk of our current decisions and are influenced by future factors of actions and the environment [13]. In other words, risk involves doubt in the case of present decisions that may have adverse consequences for decision-makers [13].

In conducting their business, insurance companies themselves are exposed to numerous risks [8]. The most important risk for an insurance company is insurance risk [13]. Insurance risk arises from the inability of the company to absorb the assumed risks inherent in the insurance business [17]. The following risks can be identified as particularly important for insurance companies [13, 8]:

- the risk of inadequately determined insurance premiums - insurance prices,

- the risk of inadequate risk assessment,

- the risk of inadequately determined self-restraint by the insurance company,

- risk of poor tariff policy of the company and inadequately defined insurance conditions.

Insurance companies are economic entities and their primary objective, in addition to protecting assets as a primary function of insurance, is to make a profit. In order for insurance companies to bear the great material consequences of realizing the risks, they must have high insurance funds and, above all, carry out a qualitative assessment of the risks they take into coverage [13].

\section{INSURANCE RISK ASSESSMENT METHODOLOGY}

The number and variety of risks that are within the scope of the modern insurance industry are increasing day by day [8]. The presence of a growing number of risks that could endanger the business of insurance companies has contributed to raising awareness of the necessity of implementing the so-called risk management activities in business processes. Raising awareness of the need and importance of the risk management process in all spheres of business activities has resulted in continuous improvement of a methodology aimed at reducing risk [13].

Effective risk management involves the identification of potentially risky (adverse) events $[13,6,14]$. This is the phase of identifying, classifying and ranking all those risky events that can trigger the insured event, so we can say that the main goal of this phase is to identify potential situations in which damage occurs, i.e. recognizing the risks that may be the active cause of the damage, as well as the hazards that may exacerbate the effects of those risks. Once identified, the risks should be analyzed. At this stage, an analysis of all the risk impacts identified as indicators of the realization of the insured event is made [13]. This process involves decomposing risk into risk factors and determining the significance and interplay of these factors [17]. As risks are identified and analyzed, it is possible to proceed with the next phase of the risk management process, i.e. risk assessment. Risk assessment is the systematic process of describing and quantifying the risks associated with dangerous events, processes, actions or substances [4]. Thus, at this stage, all factors that are relevant to the possibility of an insured event occurrence are considered and their quantification is carried out. By implementing the above steps, we get the image of the possibility of accepting a specific risk in insurance. However, the persistently present possibility of inadequate risk assessment is one of the key risks for an insurance company, and this issue needs to be specially analyzed [13]. 
A qualitative assessment of the risks that are taken into insurance coverage is crucial to the functioning of the entire insurance system [13]. Risk assessment creates the basis for an objective determination of the insurance premium, i.e. the real risk is harmonized with the insurance premium allocations [17, 7]. In addition, risk assessment provides the basis for further risk management through risk allocation. Accordingly, inadequate risk assessment results in the definition of an unrealistic risk price, as well as the possible self-adherence of an insurance company [13]. Such an outcome can seriously jeopardize the solvency of society and, therefore, its survival in the market.

The price of risk is expressed by the insurance premium through the risk premium, which depends on the expected frequency of damage and the expected amount of average damage [7]. In order to perform a quality risk assessment, it is very important to properly evaluate these two components, i.e. to form a database with historical data on the realization of risk, while the amount of possible damage depends on many factors that need to be considered individually [13].

Various risk assessment methods integrate the variations of the elements that are assessed when forming a tariff [13]. Modern scientific and technological developments have contributed to the development of numerous risk assessment methods. Some of the methods that are widely used are SEPTRI, APELL, Rapid Risk Ranking Method, Failure Tree and Event Tree, Occupational Risk Assessment Method, etc.The primary purpose of applying these methods is to provide the information on risk quantification or its qualitative qualification based on the input dataset. Risk assessment methods differ from one another in terms of risk determination, i.e. the elements (factors) by which the risk is expressed [13]. However, regardless of the differences, the task of each of them is to determine the probability of occurrence (frequency) and the consequences of the occurrence of events (amount of damage, i.e. intensity), because it is these factors that form the basis for risk assessment [13]. All this applies to the risks in working and living environment, which are increasingly present in modern times.

\section{REGULATIONS ON INSURANCE}

In order for a country to be able to adequately address risks, especially those related to working and living environment, it needs to have a legal system and regulations that comprehensively regulate the issue of insurance. The legal system takes into account the real needs of insurance entities - insurers, policyholders, insurance beneficiaries and contractors.

In the Republic of Serbia, two basic laws regulate the issue of insurance - the Insurance Law and the Law on Obligations.

\subsection{Insurance Law}

The Insurance Law regulates the performance of insurance activities in the Republic of Serbia, i.e. the conditions for establishing and operating insurance companies and reinsurance companies, performing insurance and reinsurance brokerage, performing insurance representation activities, supervising the performance of insurance activities, protecting the rights of the insured, insurance contractors, insurance beneficiaries and third injured parties, as well as performing insurance activities of persons from the EU Member States and foreign countries in the Republic of Serbia [10]. 
Insurance business consists of insurance, including co-insurance, reinsurance, insurance brokerage and insurance representation. An insurance company is a legal entity with its headquarters in the Republic of Serbia, and which is entered in the register of the competent authority on the basis of the license issued by the National Bank of Serbia to perform insurance activities.

Insurance of property and insurance of persons are voluntary and may only be compulsory in cases prescribed by law.

Insurance activities are the conclusion and performance of life and non-life insurance contracts, except for compulsory social insurance.

Types of life insurance are [10]:

1) Life insurance, covering:

- Life insurance on survival to a stipulated age;

- Life insurance on death;

- Life insurance on survival to a stipulated age or on death;

- Life insurance with return of premium;

2) Marriage insurance and birth insurance;

3) Annuity insurance;

4) Supplementary insurance in addition to life insurance, covering:

- Supplementary accident insurance with life insurance;

- Supplementary health insurance with life insurance;

5) Life insurance linked to units of investment funds;

6) Tontines, representing insurance in which the insured agree to jointly capitalise their contributions and to divide thus capitalised funds between those insured persons who live to a certain age, or between the heirs to the deceased insured persons;

7) Insurance with capital redemption, which is based on actuarial calculations in which the insured, in return for a single payment or periodic payments, receives payments of a specified amount in a specified period.

Types of non-life insurance are [10]:

1) Accident insurance including insurance against industrial injury and occupational disease insurance, covering:

- Agreed pecuniary benefits in the event of accident;

- Benefits in the nature of indemnity in the event of accident;

- A combination of payments;

- Payment for consequences of injuries or impairment of health or death of passengers;

2) Voluntary health insurance, covering:

- Agreed pecuniary benefits in the event of disease;

- Benefits in the nature of indemnity in the event of disease;

- A combination of payments;

3) Motor vehicles insurance covering the damage to self-propelled vehicles, except for railway rolling vehicles, and also covering vehicles that are not self-propelled, or for the loss of such vehicles;

4) Railway rolling vehicles insurance, covering the damage to railway rolling vehicles or loss of such vehicles;

5) Aircraft insurance, covering the damage or loss of aircrafts;

6) Insurance of vessels, covering the damage to or loss of such vessels (sea, river, lake, canal); 
7) Insurance of goods in transport covering the damage to goods or loss of goods, regardless of the type of transportation;

8) Property insurance against fire or other perils, covering the damage to property caused by fire, explosion, storm and other natural disasters, nuclear energy, land subsidence;

9) Other property insurance, covering the damage to property caused by machine breakdown, theft, glass shattering, hail, frost or other perils;

10) Motor liability insurance covering all types of liabilities when using self-propelled land vehicles, including carrier's liability;

11) Aircraft liability insurance covering all types of liabilities when using an aircraft including carrier's liability;

12) Vessels liability insurance covering all types of liabilities when using a vessel including carrier's liability;

13) General liability insurance covering other types of liabilities;

14) Credit insurance, covering:

- Risk of no or delayed payment due to insolvency or other events or activities;

- Export credits and other risks connected to export, trade and investment both in domestic and foreign markets;

- Installment credits;

- Mortgage and Lombard credits;

- Agricultural credits;

- Other credits and loans;

15) Suretyship insurance, guaranteeing direct or indirect fulfillment of the debtor's obligations;

16) Financial loss insurance covering the financial losses due to:

- Loss of employment;

- Insufficient income;

- Bad weather;

- Loss of profit;

- Unforeseen general expenses;

- Unforeseen operating expenses;

- Loss of market value;

- Loss of rent or income;

- Indirect operating losses;

- Other non-operating losses;

- Other financial losses;

17) Legal expenses insurance, covering court costs, attorney's fees and other costs of the proceedings;

18) Travel assistance insurance covering assistance to persons who get into difficulties while travelling or in other cases while away from their permanent or temporary residence.

An insurance company can carry out only those insurance activities for which it has been licensed by the National Bank of Serbia. An insurance company is established as a joint-stock company or as a mutual insurance company [10]. The National Bank of Serbia supervises the performance of insurance activities, that is, the supervision of the business of insurance companies.

The supervision of insurance activities is exercised by the National Bank of Serbia in order to protect the rights and interests of policyholders and other beneficiaries of insurance. 
It also performs other tasks prescribed by this Law, which contribute to maintaining and strengthening the stability of the financial system [10]. In exercising supervision referred to in paragraph 1 of this Article, the National Bank of Serbia shall assess legal compliance of an insurance undertaking, its implementation of the system of governance and risk management rules, as well as its compliance with the rules of the insurance and actuarial profession, good business practices and business ethics.

\subsection{Law on Obligations}

The Law on Obligations regulates the obligations arising from contracts, the fact of causing damage, acquisition without proper grounds, conducting transactions without authority, unilateral declaration of volition and other legally-established facts. With regard to insurance, this law regulates the conclusion of insurance contracts, rights and obligations of the parties, duration of insurance, insurance of property and persons [11].

The insurance contract obliges the insurance contractor to pay a certain amount to the insurance organization (insurer), while the organization shall assume the obligation, should an event take place which represents the case covered by insurance, to pay to the insured person, or a third party, compensation, the stipulated amount, or to do something else. The event serving as the ground for concluding insurance (an insured event) must be future, uncertain and independent of the contractor's sole will.

An insurance contract is null and void if, at the time of its conclusion, an insured event had already materialized, or it was in progress, or it was certain that it would occur, or there was no possibility of its occurring. However, if it is agreed that the insurance will cover a certain period that precedes the conclusion of the contract, the contract will be null and void only if at the time of its conclusion the interested party was aware that the insured event had already occurred, or that even then the possibility of its taking place had ceased to exist.

The insurance contract is concluded when the contractors sign the insurance policy or the list of coverage. A written offer made to the insurer for the conclusion of the insurance contract shall be binding on the offeror - unless he has determined a shorter time limit, for eight days after the offer has reached the insurer, and should medical examination be necessary, then in course of thirty days. If within that period the insurer does not decline the offer, which does not deviate from the conditions under which he performs the proposed insurance, he shall be deemed to have accepted the offer and the contract has been concluded. In this case, the contract is considered concluded when the offer reached the insurer. The policy must specify: contracting parties, the insured object or the insured person, the risk covered by the insurance, the duration of the insurance and the period of coverage, the sum of insurance or an indication that the insurance is unlimited; premium or allowance, date of issue of the policy and signatures of the contracting parties. The insurance policy may be temporarily replaced by a list of coverage that contains the essential components of the contract [11]. The fulfillment of the obligation from the previous paragraph must be stated on the policy In the case of discrepancy between a provision of the general or particular terms and conditions, and an insurance policy clause, the clause of the policy shall apply and in case of discrepancy between an insurance policy printed clause and a handwritten clause, the latter shall apply.

According to the agreement of the contractor, the policy can be made out either to a specific person, by order, or to bearer. Conditions of insurance may stipulate the cases in which a contractual relationship from insurance is created by the payment of the premium itself. 
A person concluding a contract of insurance on behalf of another without his authorization shall be liable to the insurer for obligations stemming out of such contract, until the person on whose behalf the contract is concluded has accepted it. The interested person can approve the contract even after the insured event has occurred. If the approval is refused, the insurance contractor owes a premium for the insurance period in which the insurer is notified of the refusal. But a manager without instructions shall not be liable for obligations stemming out of the insurance if he notifies the insurer of his acting without authorization and on behalf of and for the account of another.

In case of insurance on another person's account or for the account of the party interested, the duties of payment of insurance premium and other contractual obligations shall be met by the person concluding the insurance, but he shall not be entitled to effect rights on the ground of insurance, even after being in possession of the policy, without the consent of the person whose interest is insured and who is the holder of these rights.

The insurance contractor is not obliged to hand over the policy to the interested person until the premiums are paid by the insurer and the costs of the contract have been reimbursed. The insurance contractor has the right of priority in collecting these claims out of compensation due, as well as the right to demand their payment directly from the insurer. An insurer may raise all objections otherwise pertaining to him on the ground of the contract against the negotiator of insurance against every user of the insurance for another person's account [11].

Should an insurer authorize someone to represent him, while not specifying the scope of his powers, such agent shall be entitled to conclude, on behalf and for the account of the insurer, the contract of insurance, to negotiate and conclude alterations of contracts or extend their validity, to issue insurance policies, to collect premium payments, and to accept statements communicated to the insurer. Should the insurer limit his agent while this fact is not known to the negotiator of insurance, such limitations shall be considered as nonexistent.

A person concluding the insurance shall be obliged to report to the insurer, at the conclusion of the contract, all circumstances which are material in assessing the risk, and which were known, or could not have been unknown, to him. The insurance contractor shall, when it comes to property insurance, inform the insurer of any change in circumstances that may be relevant to the risk assessment, and when it comes to the insurance of persons, then only if the risk is increased because the insured person has changed occupation. He is obliged to immediately notify the insurer of the increase in risk, if the risk is increased by some of his actions, and if the increase in risk occurred without his participation, he is obliged to inform the insurer within fourteen days of being informed about it. If the risk increase is such that the insurer would not have concluded the contract if such a condition had existed at the time of its conclusion, he may terminate the contract. But, if the risk increase is so high that the insurer would have concluded the contract only at a higher premium if such condition had existed at the time of the conclusion of the contract, he may propose to the insurance contractor a new premium rate. If the insurance contractor does not agree to the new premium rate within fourteen days of receipt of the proposal of the new rate, the contract shall terminate by law. However, the contract remains in effect and the insurer can no longer use the authority to propose to the insurance contractor a new rate of premium or to terminate the contract if he does not exercise those powers within one month of learning of the increase in risk in any way, or even before the deadline if he somehow demonstrates that he agrees to the contract extension (if he receives a premium, pays for the insured event that occurred after that increase, etc.) [11]. 
Should a case covered by insurance take place prior to notifying the insurer of the increase in risk, or if he was notified of the increase in risk, but prior to the termination of the contract by him or reaching an agreement with the negotiator of insurance regarding the increase of insurance premium, the compensation shall be reduced proportionately to the premiums already paid and those which would have to be paid according to the increased risk.

Should after entering into contract of insurance, a reduction of risk takes place, the insurance contractor shall be entitled to demand a corresponding reduction of insurance premium, counting from the day of his notifying the insurer of such reduction of risk. Should the insurer fail to accept the reduction of insurance premiums, the insurance contractor may terminate the contract. Except in the case of life insurance, the insured person shall be obliged to notify the insurer about the occurrence of the event covered by insurance, within three days at the latest, counting from the day of his becoming aware of it. Should he fail to fulfill this obligation within the designated time, he shall be obliged to compensate the insurer for loss sustained due to the above [11].

When the event covered by insurance takes place, the insurer shall be bound to pay the compensation or the amount specified by contract within the stipulated time limit which shall not exceed fourteen days, counting from the notification received by the insurer of the occurrence of the insured event. If the insurance contractor, the insured person or the beneficiary of insurance provoked the event covered by insurance by their will full misconduct or fraud, the insurer shall have no obligation whatsoever, while a contractual clause contrary to that shall have no legal effect.

Unless otherwise stipulated, the contract of insurance shall begin to take effect twenty four hours from the day designated in the insurance policy as the day of commencement of insurance, and shall continue to be effective until the end of the last day of the time limit stipulated for the insurance. Should an insurance time limit be not provided by contract, each party shall be entitled to terminate the contract on the day of maturity of the insurance premium, after notifying the other party accordingly in writing, three months before the maturity of the premium, at the latest. Should insurance be stipulated for a period exceeding five years, each party shall be entitled, after the expiration of that time limit, to notify the other party by letter of its intent to rescind the contract, honouring the six months of notice. It shall not be possible to exclude by contract the right of each party to terminate the contract as specified above. This shall not apply to life insurance.

Property insurance may be contracted by any person having an interest that the insured event does not take place since otherwise such a person would suffer a material loss. The insurance rights may pertain only to persons having a material interest that the insured event does not take place at the moment of occurrence of damage. Property insurance provides compensation for the damage that would occur in the property of the insured due to the occurrence of the insured event. The amount of compensation may not be greater than the damage suffered by the insured by the occurrence of the insured event [11].

In the case of crop insurance, or insurance of other agricultural products, the amount of damage shall be determined in relation to the value such crop would have at the time of harvest unless otherwise provided by the contract.

Clauses of a contract by which the amount of compensation is limited to a sum which is lower than the amount of damage shall be valid. In assessing the amount of damage, the profit lost shall be taken into consideration only if so provided by the contract. Should in course of the same period of insurance several insured events take place one after the 
other, the insurance compensation for each one of them shall be determined and paid off entirely by taking in consideration the total amount insured, without reducing it by the amount of compensation previously paid within such period. Should the value of the insured object be determined by agreement, the compensation shall be determined according to such value, unless the insurer is successful in proving that the value stipulated is excessively higher than the real value, and that there is no justified ground for such difference (for instance, insuring a used object at the value of a new one, or insuring a subjective, personal, value). An insured person shall be obliged to take regulated, stipulated, and all other necessary measures to prevent the occurrence of the insured event, and if such an event does take place, he shall be obliged to take every possible measure to limit consequential damage. The insurer shall be obliged to compensate expenses, losses, and other losses caused by reasonable attempts to eliminate the direct danger of occurrence of the insured event, including that caused by an attempt to limit its damaging consequences, even if such attempts are not successful. The insurer shall be obliged to pay such compensation even if, taken together with compensation of damage from the insured event, it exceeds the amount of insurance. Should the insured person fail to fulfill his obligation to prevent the occurrence of the insured event, or the obligation of salvage, while having no justified reason, the obligation of the insurer shall be reduced by an amount equal to the increase of damage due to such omission. The insurer shall not be liable for damage to the insured item which originates from its defects, unless otherwise agreed [11].

An insurer shall not be obliged to redress damage caused by war operations or rebellions unless otherwise provided by the contract.

In the case of liability insurance, the insurer is liable for damage caused by the insured event only if the third injured party claims its compensation.

The insurer shall bear, within the limits of the amount of insurance, the expenses of litigation over the liability of the insured person.

In case of liability insurance, the person sustaining damage may request the compensation for the loss sustained due to an event falling within the sphere of liability of the insured person directly from the insurer, but only up to the amount of the insurer's obligation.

The person sustaining damage shall have, from the day of occurrence of the insured event, his right to compensation from the insurance, so that any subsequent change in the insured person's rights against the insurer shall not affect the right of a person sustaining damage to compensation.

In contracts of insurance of persons (life insurance and accident insurance), the amount of insurance to be paid by the insurer on the occurrence of the insured event shall be determined in the insurance policy by agreement between the contracting parties.

In addition to elements which are constituent for every insurance policy, the life insurance policy shall include indications of the name and last name of a person whose life is insured, his date of birth and event or time limit being a prerequisite for requesting payment of the amount insured.

The life insurance policy may be made out to a specific person or order, but it shall not be made out to the bearer.

For an endorsement of the insurance policy made out to order to be full and valid, it must contain an indication of the name of the beneficiary, the date of endorsing and the signature of the endorser.

The contract of insurance covering the case of death shall not include the risk of suicide of the insured person if it happened in the first year of the insurance period. If the 
suicide happens within three years from the day of entering into the contract, the insurer shall not be obliged to pay to the beneficiary the insured amount, but only the mathematical reserve of the contract.

An insurer shall be released from the obligation to pay to the beneficiary the insured amount if he willfully caused the death of the insured person, but if until then at least three annual insurance premiums have been paid, he shall be obliged to pay the mathematical reserve to the negotiator of insurance, and should he be the insured person, the payment shall be made to his successors. An insurer shall be released from obligation in the insurance contract covering an accident if the insured person wilfully caused the accident.

Should the death of the insured person be caused by war operations, the insurer - unless otherwise provided by contract - shall not be bound to pay to the beneficiary the insured amount, but shall be obliged to pay to him the mathematical reserve from the contract. Unless otherwise provided by contract, the insurer shall be released from obligation from the accident insurance contract, if the accident was caused by war operations. Other risks may also be excluded by contract covering cases of death or accident [11].

\section{CONCLUSION}

Analyzing insurance from the perspective of risk in working and living environment requires a clear definition of these risks in the first place. Environmental risks are a measure of the probability that activity causes a danger to the environment, life and health directly or indirectly [9]. It is an indicator of the likelihood of the loss of life, health and property damage or environmental damage due to the exposure to a given environmental hazard. Also, it may be considered as an environmental hazard and exposure to environmental hazards. Risks in the working environment are the risks that occur in the workplace, endangering the life and health of the employees while performing their jobs (working at altitude, outdoors, underground). It is the likelihood of an injury, illness or damage to an employee's health due to a hazard [15]. It is also a violation of the physical (damage or destruction of certain organs or parts of organs, or impairment of the harmonious functioning of certain body parts), psychical (loss of the ability for uniform and harmonious behavior) and moral integrity (violation of dignity) of the employee.

Considering the extent to which these risks are present in nature and society, their assessment, management and insurance are very important [2], as well as consistent adherence to the principles of prevention. In order for these activities to be properly carried out, legal regulations play an important role. Insurance regulations (generally speaking of all types of insurance) are very important for establishing legal protection in risk management. For the time being, there is neither a law on occupational injury insurance nor a law on environmental damage insurance in the Republic of Serbia. However, both of these legal documents are under preparation, more precisely, they are still in the process of being drafted, but their adoption is certain. When these two laws are adopted and put into effect in the Republic of Serbia, it will be a complete turnaround in the system of risk insurance in living and working environment.

Acknowledgement: This research was funded by the Ministry of Education, Science and Technological Development of the Republic of Serbia. 


\section{REFERENCES}

1. Andrijanić I., Klasić K., (2002), Tehnika osiguranja i reosiguranja (Insurance and Reinsurance Technique), Mikrorad, Zagreb.

2. Avdalović V., Ćosić Đ., Avdalović S., (2008), Upravljanje rizikom u osiguranju (Risk Management in Insurance), Fakultet tehničkih nauka, Novi Sad.

3. Avdalović S., Ćosić Đ., Avdalović V., (2010), Osnove osiguranja sa upravljanjem rizikom (Basics of Insurance with Risk Management), Fakultet tehničkih nauka, Novi Sad.

4. Covello V., Merkhoffer M., (1993), Risk Assessment Methods, Plenum Press, New York.

5. Ćosić Đ. at al., Microfinance Products as Tool for Financial Resilience to Hazards, Proceedings of the 2. K-FORCE: Knowledge for resilient society Conference, Tirana, 2019, pp. 59-64.

6. Ćosić Đ., Popov S., Sakulski D., Frank A., Geo-Information Technology for Disaster Risk Assessment, Acta Geotechnica Slovenica, Vol. 8, No. 1, 2011, pp. 65-74.

7. Ćosić Đ., Popov S., Novaković T., Popović Lj., Flood Damage Assessment Method: GIS Based Approach, Fresenius Environmental Bulletin, Vol. 28, No. 3, 2019, pp. 1896-1904.

8. Decision on the System of Internal Controls and Risk Management in the Business of Insurance Companies, Official Gazette of the Republic of Serbia, No. 12/2007.

9. Environmental Protection Law, Official Gazette of the Republic of Serbia, No. 135/2004, 36/2009, 36/2009, 72/2009, 43/2011, 14/2016, 76/2018, 95/2018, 95/2018

10. Insurance law, Official Gazette of the Republic of Serbia, No. 139/2014

11. Law on Obligations, "Official Journal SFRJ", No. 29/1978, 39/1985, 45/1989, 57/1989,"Official Journal SRJ", No. 31/1993, "Official Journal SCG", No. 1/2003 and Official Gazette of the Republic of Serbia, No. $18 / 2020$.

12. Mrkšić D., Ćosić Đ., (2015), Upravljanje rizikom i osiguranje (Risk Management and Insurance), Fakultet tehničkih nauka, Novi Sad.

13. Novaković T., Popović Lj., Simić J., Popov S., Ćosić Đ., Primena GISa u menadžmentu osiguranja (Application of GIS in Insurance Management), Zbornik radova sa Naučno-stručnog skupa Preduzetništvo, inženjerstvo i menadžment, Zrenjanin, 2014, str. 364-371.

14. Novaković T. at all., Subject „Disaster Risk Management“ - Spatial Context, ITRO - a Journal for Information Technology, Education Development and Teaching Methods of Technical and Natural Sciences, Vol. 3, No. 1, 2013, pp. 81-88.

15. Occupational Safety and Health Act, Official Gazette of the Republic of Serbia, No. 101/2005, 91/2015, $113 / 2017$.

16. Petrović E., Avdalović V., (2011), Menadžment rizika i osiguranje (Risk Management and Insurance), Ekonomski fakultet, Niš.

17. Vujović R., (2009), Upravljanje rizicima i osiguranje (Risk Management and Insurance), Univerzitet Singidunum, Beograd.

\section{OSIGURANJE KAO PRETPOSTAVKA UPRAVLJANJA RIZICIMA U RADNOJ I ŽIVOTNOJ SREDINI}

Osiguranje predstavlja privrednu, uslužnu delatnost koja štiti čoveka i njegovu imovinu od posledica nastupanja brojnih opasnosti. Pri tome, osiguravajuća društva susreću se sa rizikom od nastanka finansijskog gubitka. Neadekvatno utvrđene premije osiguranja usled neadekvatne procene rizika koji se preuzima u osiguranje prepoznate su kao najčešći uzrok ovih gubitaka. Kako bi mogućnost neželjenih gubitaka bila svedena na minimum neophodno je sprovođenje adekvatnih aktivnosti upravljanja poslovnim procesima osiguranja. Pri tome, posebnu pažnju potrebno je posvetiti procesu procene rizika. Kvalitetna procena rizika od izuzetnog je značaja za funkcionisanje celokupnog sistema osiguranja. Samo osiguranje može imati veoma značajnu ulogu u upravljanju rizicima u radnoj životnoj sredini, a pravno uređenje obavljanja ovih poslova uliva sigurnost subjektima osiguranja.

Ključne reči: osiguranje, procena rizika, radna i životna sredina, propisi 